\title{
Comment for the Special Issue of Smallpox and Measles
}

\section{Margret Gudnadottir}

Professor Emeritus, Department of Microbiology, University of Iceland, Iceland

*Corresponding author: Margret Gudnadottir, Professor Emeritus, Department of Microbiology, University of Iceland, Iceland, Tel: 3545254000; E-mail: ef@ismennt.is

Received date: 25 Aug 2014; Accepted date: 18 Sep 2014; Published date: 25 Sep 2014

Copyright: ( 2014 Gudnadottir M. This is an open-access article distributed under the terms of the Creative Commons Attribution License, which permits unrestricted use, distribution, and reproduction in any medium, provided the original author and source are credited.

\section{Comment}

In 1796, Dr Jenner did a crucial experiment: by simply transferring fluid from original cowpox lesions to mild abrasions on human skin. Smallpox infection on the treated people in his medical district in the coming epidemics was successfully prevented, as many cowpox infected people had claimed. From his experiments until October 1977, when the last smallpox patient was found in Somalia, 181 years passed. Now, the world has been free of smallpox for 37 years. Eradication of this terrible disease is one of the greatest successes in the history of medicine.

After Dr. Enders' success when growing poliovirus in human cell tissue culture, in 1949, polio vaccines became available. Polio is now a rare infection only found in very few countries and is in real danger of being eradicated, especially if all human beings have access to clean water in not so far future.
Before 1970 good living attenuated measles vaccine was developed and is now available in all countries with proper health care. Yet we still have too many cases of measles in these countries because of poor participation in their vaccine programs. The measles virus has only one immunogenic strain, just like the human smallpox virus had, and is therefore a good candidate for being eradicated the same way. Malnutrition of small children is a main health problem in far too many poor countries, whereas obesity is the big killer in the wealthier parts of the world. Malnutrition of young vaccinees might interfere with use of even a mild life attenuated vaccine, well tolerated by properly nourished children in healthier environment. Those who fight infectious diseases have to remember that proper housing, clean water and proper nutrition are the basic factors necessary to get rid of so many infections that are killing people who do not have access to these most important needs of us all. 